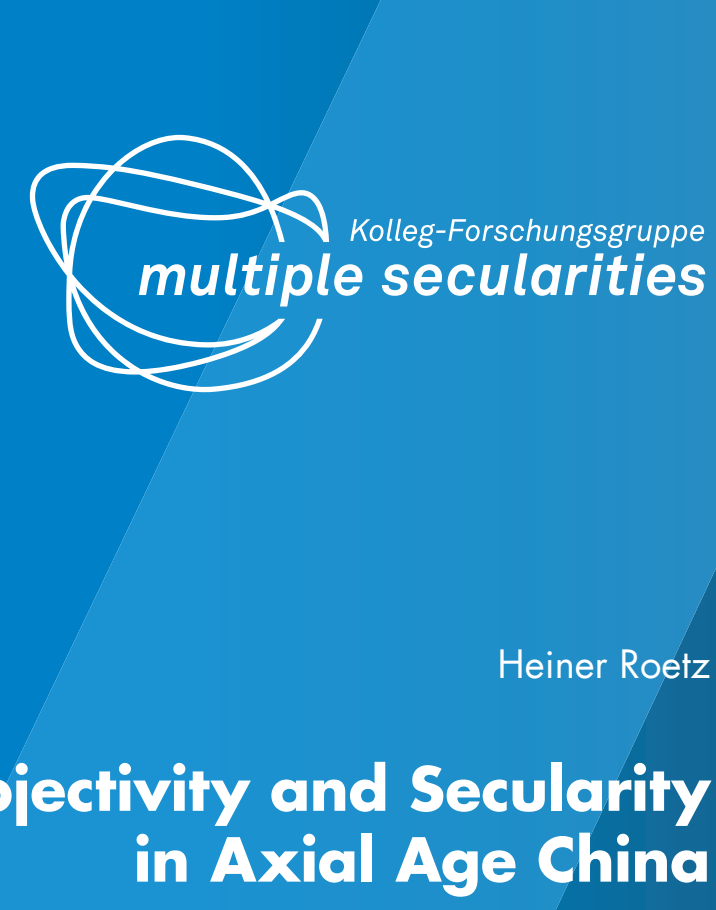

Working Paper \# 17 
Working Paper Series of the HCAS

"Multiple Secularities - Beyond the West, Beyond Modernities"

\#17: Heiner Roetz. "On Subjectivity and Secularity in Axial Age China."

Leipzig University, 2020.

(C) Heiner Roetz

This Working Paper has been published online and can be downloaded from www.multiple-secularities.de/publications/working-papers or ordered in print via email to multiple-secularities@uni-leipzig.de

The HCAS's Working Paper Series serves to disseminate the results of work in progress prior to publication to encourage the exchange of ideas and academic debate. Inclusion of a paper in the Working Paper Series should not limit publication in any other venue. Copyright remains with the authors.

Please cite as:

Roetz, Heiner. "On Subjectivity and Secularity in Axial Age China." Working Paper Series of the HCAS "Multiple Secularities - Beyond the West, Beyond Modernities" 17. Leipzig University, 2020.

Leipzig University

HCAS "Multiple Secularities - Beyond the West, Beyond Modernities"

Nikolaistraße 8-10

04109 Leipzig

Germany

The HCAS is part of Leipzig University and funded by the German Research Foundation (DFG).

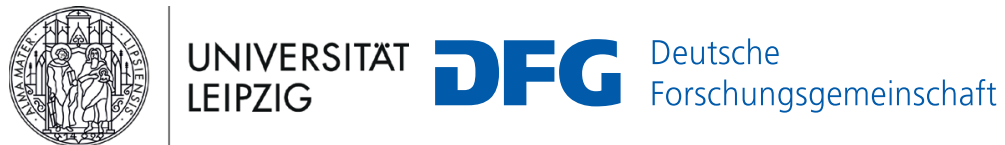




\section{On Subjectivity and Secularity in Axial Age China}

The Humanities Centre for Advanced Studies "Multiple Secularities Beyond the West, Beyond Modernities" deals with topics, at least some of which I have myself dealt with throughout my sinological and philosophical life. ${ }^{1}$ I came to Frankfurt in autumn 1968: fascinated by Frankfurt School, I started studying sociology, but to my surprise this did not mean studying Critical Theory. Instead, it meant going through quite a conventional education in the social sciences, and moreover, it meant studying economics and statistics. This was not quite what I expected and after a few semesters I changed my major to philosophy. In need of a second subject, I chose sinology because of some vague interest in foreign cultures, and also because of the news coming from China at that time. It was the time of the Cultural Revolution that exerted a certain fascination on the German student movement especially since its revolutionary rhetoric differed so remarkably from the ossified language of Eastern European Marxist orthodoxy. So, like many members of my generation, I began to develop an interest in revolutionary China that was definitely not shared by my philosophy teachers - they were skeptical, at least to some extent. ${ }^{2}$

Nevertheless, one member of Frankfurt School, Alfred Schmidt, once asked me if I knew of any significant Chinese contributions to the theory of Marxism that should be considered seriously within international discussions on Marx. Schmidt himself had quoted Mao's On Practice two or three times in his works, though somewhat patronizingly - he was not convinced that Mao was a great philosopher. His question really caused me to think, and it was not easy to find an answer. Finally, I decided it might be interesting to look at a recurrent topic of Maoist rhetoric and theory: the "victory of the subjective over the objective." This was totally at odds with the stress on objective law in orthodox Marxism as per Marx' famous phrase Das Sein bestimmt das Bewusstsein - Being determines consciousness. As a matter of fact, Mao Zedong was criticized for it by Soviet

1 This Working Paper is based on a lecture given at the Colloquium of the HCAS "Multiple Secularities - Beyond the West, Beyond Modernities" at Leipzig University on January 23, 2019.

2 See Heiner Roetz, "Erinnerung: 50 Jahre Kulturrevolution," Bochumer Jahrbuch zur Ostasienforschung 39 (2016). 
ideologues, supported among others by East German sinologists, including some here in Leipzig, and reproached for petty bourgeois 'subjectivism' that simply tried to bypass objectively necessary phases of development. In contrast to this orthodox critique, the Maoist position shared some similarities with the Frankfurt 'Western Marxist' reading of Marx' phrase, which was not understood as expressing an objective eternal historical law but as a critique of capitalism. The sentence would thus mean that, up until this point, mankind had only been determined by 'being,' but that it was now time to consciously take its own history into its own hands. This was the reverse interpretation of the one given by orthodox Marxism. Therefore, there seemed to be some common ground between the Chinese and Frankfurt positions, and I started to look at the matter of Subjektivität, which has continued to occupy me to this day, as well as the associated problems that turned out to be key in shedding some light on the course of Chinese history.

The question of Subjektivität soon led me away from Maoist China to the deeper historical layers of Chinese philosophy, since one German sinologist - Tilemann Grimm, who was my pre-predecessor at Bochum University - said that Mao was actually influenced by the Chinese philosopher Wang Yangming 王陽明 who lived around 1500. However, Wang Yangming was influenced by the ancient Confucian philosopher Mengzi 孟子 from the $4^{\text {th }}$ century BCE who - because of his moral voluntarism was also identified as one of Mao's forerunners by my sinological teacher, Professor Chang Tsung-tung. Chang believed that Mao's famous statement that the atomic bomb was just a paper tiger was inspired by Mengzi's voluntarism, and Mao actually did have knowledge of Chinese philosophy.

Thus my question led me to Chinese antiquity where I have remained ever since, but without giving up my original interest in contemporary China - I have always tried to bridge that gap. However, when searching for the sources of subjectivity in China, I soon encountered theories that utterly contradicted the views of Grimm and Chang Tsung-tung and maintained that subjectivity was something fundamentally absent from Chinese culture. Hegel is a classic example: he sees China as the eternal kingdom of unresolved "Substanz." As he writes in his Lectures on the Philosophy of World History (I): 
Together with more free reflection, the ethical separates from the legal. Then the constitution rests on the legal which brings forth laws while the ethical is left to the individual. [...] Nothing should appear in the laws what is free inside and has its being in the subject. In our modern consciousness we have the idea that the inner life of the human being should be respected. This demand expresses itself in the form of honor. It refers to the unimpeachable realm of what I am for myself. [...] It is a never-ending injury for me if someone touches this sphere in a hostile manner. This honor presupposes the sanctity of my being for myself. However, if someone rules over me morally, then my being for myself is not respected, and there is no room for honor here, and likewise not for the productions which come from my inwardness. That this is the case in China remains to be concretely shown. ${ }^{3}$

According to Hegel, the separation of the legal and the ethical, and the inclusion of the latter in an individual's inner make-up as morality, is the condition of 'subjective freedom' or 'free subjectivity', whereby selfunderstanding develops from itself rather being derived from past models. However, subjectivity is lacking in China. China remains in the grip of 'substance, the antonym of subjectivity. Substance represents the unmoved and unquestioned authority of tradition and of the given power structures, and the absence of any inwardness of conscience and morality, the space for which is completely occupied by external forces. This has grave implications since, for Hegel, the principle of free subjectivity counts as the "principle of the modern world"4 or of "modern times."5 China is therefore excluded from modernity. And should there be something similar to modernity in China, it must be imported while abandoning Chinese

3 G. W. F. Hegel, Vorlesungen zur Philosophie der Weltgeschichte (Leipzig: Meiner, 1920), 300: "Bei freierer Reflexion scheidet sich das Sittliche von dem Rechtlichen ab. Dann beruht die Verfassung auf dem Rechte, und aus ihm gehen Gesetze hervor, während die Sittlichkeit dem Individuum überlassen wird [...] In den Gesetzen sollte nichts auftreten dürfen, was innerlich frei ist und sein Dasein in dem Subjekte hat. In unserm modernen Bewusstsein tragen wir die Vorstellung, dass diese Innerlichkeit an dem Menschen respektiert werden soll. Diese Forderung drückt sich in der Form der Ehre aus. Sie betrifft den unantastbaren Kreis dessen, was ich für mich bin. [...] Es ist für mich eine unendliche Verletzung, wenn jemand diese Sphäre feindlich berührt. Die Ehre setzt Unantastbarkeit meines Fürmichseins voraus. Wird aber moralisch über mich regiert, so ist mein Fürmichsein nicht respektiert, und die Ehre hat hier keinen Raum, so wenig wie die Produktionen, die aus meiner Innerlichkeit hervorgehen. Dass es in China so ist, bleibt uns noch in konkreten Zügen nachzuweisen."

4 G. W. F. Hegel, Grundlinien der Philosophie des Rechts, vol. 7 of Werke (Frankfurt/M.: Suhrkamp, 1986), \$273.

5 Hegel, Philosophie des Rechts, $\$ 124$. 
traditions. This has consequences with regard to the possibility of modern institutions, such as democracy, which would not be conceivable within a genuine Chinese context. This has remained a topic of debate to this day.

What is the reason for the "stataric" (statarisch), unmoved conditions of China, as Hegel puts it? Hegel identifies an important religious source: there is only a world-immanent form of religion without transcendence. As he says in his Lectures on the Philosophy of Religion:

The Heaven of the Chinese, therefore, is not a world which forms an independent realm above the earth, and which is in its own right the realm of the Ideal, like the Heaven we conceive of, with angels and the souls of the departed; nor is it like the Greek Olympus, which is distinct from life on earth. Here, on the contrary, everything is on earth, and all that has power is subject to the Emperor $[\ldots] .^{6}$

Here, we have the locus classicus of the thesis on Chinese culture as a culture of pure immanence without transcendence. This idea has been repeated again and again, for example by Schelling in his Philosophie der Mythologie. To Schelling, the main factor behind understanding why "the patriarchal principle has maintained its influence and power for thousands of years" in China, is the abrupt change of the religion of Heaven into the deification of the state - "religio astralis in rempublicam versa." This means an "absolute secularization of the religious principle" which bestows a religious aura upon institutions. ${ }^{7}$ The Chinese world is marked by a secularity which is not distinct from sacrality but identical to it. In the Chinese "religion of nature," everything is both at the same time. In this compact world, where everything is holy, there is no leeway for subjectivity to develop.

Thus, the alleged absence of subjectivity in China would be part of a syndrome of magic immanence, the compactness of which does not allow for any of the distinctions that form the self-understanding of 'Western' modernity, with an early start in Greek antiquity, among them the distinction between

6 G. W. F. Hegel, Vorlesungen über die Philosophie der Religion, vol. 16 of Werke (Frankfurt/M.: Suhrkamp, 1986), 320: "Der Himmel der Chinesen ist daher nicht eine Welt, die über der Erde ein selbständiges Reich bildet und für sich das Reich des Idealen ist, wie wir uns den Himmel mit Engeln und den Seelen der Verstorbenen vorstellen oder wie der griechische Olymp vom Leben auf der Erde unterschieden ist, sondern alles ist auf Erden, und alles, was Macht hat, ist dem Kaiser unterworfen [...]."

7 F. W. J. Schelling, Philosophie der Mythologie, vol. 1 (Darmstadt: Wissenschaftliche Buchgesellschaft, 1957 [1856]), 531, 539.

8 Hegel, Philosophie der Religion. 
the secular and the sacred. This paradigm of total immanence without distinctions established by Hegel has been the basis of the standard Western view of China to this day. By way of example, it has been reinforced by the Durkheim school in France; by Max Weber in his study on Konfuzianismus und Taoismus, together with the argument that, as part of the Chinese this-worldliness without any 'tension,' the world remains a "magic garden" and "any striving for transcendent values and destinies" is missing;" by Talcott Parsons in the English-speaking world, ${ }^{10}$ and many others. I skip all the statements that could be quoted here and limit myself to the Heideggerian philosopher of language, Johannes Lohmann, as an important representative of the linguistic approach ${ }^{11}$ to explain the phenomenon in question. Lohmann writes:

Chinese thought is, as standing in the ontological indifference, a-dihairetical; this becomes apparent everywhere. What we take apart remains together here, theory and practice, logical and ethical law, rational and intuitive cognition (ratio and divinatio, mathematics and mantic arts), knowledge and belief, world ('Heaven') and God are not separated. ${ }^{12}$

According to Lohmann, the 'ontological indifference' that China is incapable of overcoming is rooted in the structure of Chinese language. ${ }^{13} \mathrm{In}$ Chinese, he maintains, "the order of language is by itself the immediate image of a real order to which the speaker adjusts himself." ${ }^{14}$ Thus language is unable to create any distance between the speaker and the world. According to Lohmann, this further explains the modern situation in China. In view of the continuation of Communist rule in China, he comments:

9 Max Weber, “Konfuzianismus und Taoismus," in Gesammelte Aufsätze zur Religionssoziologie I (Tübingen: Mohr, 1920), 513, 434.

10 Talcott Parsons, The Structure of Social Action (New York, NY: Free Press, 1937), 548-49; Heiner Roetz, Confucian Ethics of the Axial Age (Albany, NY: SUNY Press, 1993), 19-21.

11 On this topic, see Heiner Roetz, "Die Chinesische Sprache und das Chinesische Denken: Positionen einer Debatte," in Bochumer Jahrbuch zur Ostasienforschung 30 (2006).

12 Johannes Lohmann, "Martin Heideggers ontologische Indifferenz und die Sprache," Lexis 1 (1948): 76: "Das chinesische Denken ist, als in der 'ontologischen Indifferenz' verlaufend, überhaupt a-dihäretisch, das zeigt sich in allen Stücken. Was bei uns auseinandergenommen wird, bleibt hier zusammen, Theorie und Praxis, logisches und ethisches Gesetz, rationale und intuitive Erkenntnis (ratio und divinatio, Mathematik und Mantik), Wissen und Glauben, Welt ('Himmel') und Gott werden nicht geschieden."

13 See Roetz, Confucian Ethics, 13; Roetz, "Die Chinesische Sprache," 16-23.

14 Johannes Lohmann, Philosophie und Sprachwissenschaft (Berlin: Duncker \& Humblot, 1965), 183: "In der semantischen Form der ontologischen Indifferenz [...] ist die Ordnung der Sprache an sich schon das unmittelbare Abbild einer realen Ordnung, in die der Sprechende sich selbst einordnet." 
Till today, the Chinese have not managed to take this step (to overcome the ontological indifference), which was made in Europe 3000 years ago, because at the cradle of their culture - inspired by the form of language - stands the idea of the immediate objectivation of the term. It is now so firmly rooted that even the brutality of a super-communist regime seems not to succeed to make a new beginning in this respect which would correspond to the present world-situation of a Europeanized universe. ${ }^{15}$

Thus, Chinese immanence would have grave historical, if not worldhistorical consequences. Actually, the Hegel-Weber Paradigm, as I call it, has implications for each of the three "contests in which men are engaged" (man and nature, man and man, man and himself) or "actor-world-relations" (to the objective, the social and the subjective world) distinguished by Bertrand Russell ${ }^{16}$ and Jürgen Habermas. ${ }^{17}$ They can be brought into the following scheme:

\section{The Hegel-Weber Paradigm}

'Immanent' Religion (IR)

Typical case: Confucianism

This-worldliness $=$ adaptation to the world

\section{'Transcendent' Religion (TR)}

Typical case: Puritanism

Other-worldliness $=$ tension to the world

Consequences for the actor-world relations through absence (IR) or presence (TR) of 'leverage'

Subject - Object (natural world)

Unbroken unity with nature

Disenchantment and subjugation of nature

Subject - Co-subjects (social world)

Reification of the given order

Questioning of the given order

Subject - Subject (inner world of the self)

Collective identity
Development of subjectivity

15 Lohmann, Philosophie und Sprachwissenschaft, 174: "Den Chinesen aber ist bis heute dieser Schritt (die Überwindung der ontologischen Indifferenz, der Identifizierung von Begriff und Gegenstand), der in Europa vor fast 3000 Jahren erfolgte, nicht gelungen, weil an der Wiege ihrer Kultur - von der Form der Silben-Sprache her angeregt - die Idee der unmittelbaren Objektivation des Begriffes steht, die nunmehr derart fest eingewurzelt ist, dass es heute selbst der Brutalität eines super-kommunistischen Regimes nicht zu gelingen scheint, in dieser Hinsicht einen neuen, dem heutigen Welt-Zustande eines europäisierten Universums entsprechenden neuen Anfang zu setzen."

16 Bertrand Russell, New Hopes for a Changing World (London: George Allen and Unwin, 1951), 18.

17 Jürgen Habermas, Handlungsrationalität und gesellschaftliche Rationalisierung, vol. 1 of Theorie des kommunikativen Handelns (Frankfurt/M.: Suhrkamp, 1985), 145. 
Much of the discussion initiated by Hegel follows this framework. However, it is not as convincing as it might appear at first glance. I personally critiqued the first relation (S-O) as part of my doctoral thesis Mensch und Natur im alten China ${ }^{18}$ and the second relation (S-CS) in my work Die chinesische Ethik der Achsenzeit..$^{19}$ I have not had and most probably will not have time to cover the third relation (S-S), except in some book passages and articles.

The Hegel-Weber paradigm has also profoundly influenced Chinese Studies, though there is certainly no unanimous view of Chinese culture. The idea of the secular as the sacred itself, which resolves the difference in favor of a normatively charged holism comprising the holiness of Earthly institutions, has reappeared affirmatively in a 'watershed book' by Herbert Fingarette, ${ }^{20}$ who is obviously unaware of its history (Davis recommends it as a "classic of comparative religious ethics"). This book, that reads Gilbert Ryle's behaviorism into Confucianism, has had a tremendous impact on the recent study of Confucian culture. It presents the Confucian world as guided by the 'magical' power of everyday ritual as 'sacred ceremony', where "each person does what he is supposed to do according to a pattern" without any "subjective states" or "inner psychic life." ${ }^{11}$ We follow "tradition and convention" as "holy rite,"22 "not because we find it to be right, but by virtue of its defining for us what we are to value as right." ${ }^{23}$ These "powerful guides" preclude the need for any subjective awareness, for they "have their own autonomous authority independently of consequences."

In a similar vein, David Hall and Roger Ames have maintained that the Chinese conception of humaneness does not presuppose any notion of a moral order transcending the consensual order that could justify either demagogic appeals or appeals to individual conscience, and that might disrupt the consensus. ${ }^{25}$

18 Heiner Roetz, Mensch und Natur im alten China (Frankfurt/M.: P. Lang, 1984).

19 Heiner Roetz, Die chinesische Ethik der Achsenzeit (Frankfurt/M.: Suhrkamp, 1992) and the English translation Roetz, Confucian Ethics.

20 Herbert Fingarette, Confucius: The Secular as Sacred (New York, NY: Harper Torchbooks, 1972).

21 Fingarette, Confucius, 7, 40, 45.

22 Fingarette, 7.

23 Herbert Fingarette, "Reason, Spontaneity, and the Li: A Confucian Critique of Graham's Solution to the Problem of Fact and Value," in Chinese Texts and Philosophical Contexts: Essays Dedicated to Angus C. Graham, ed. Henry Rosemont (La Salle: Open Court, 1991), 218.

24 Fingarette, "Reason, Spontaneity, and the $L i$, " 219.

25 David Hall and Roger Ames, Thinking from the Han: Self, Truth and Transcendence in 
Virginia Suddath has further elaborated this idea in her doctoral dissertation on remonstrance in Confucianism. According to Suddath,

there is no soteriology in Confucianism beyond the socio-political realm. There is no conception of a better world beyond this one, no appeal for legitimation to a transcendent realm. ${ }^{26}$

With Ames, she contends that the form of "protest" in accordance with the "Chinese world order" is "ineffectual in mounting substantive challenge to prevailing modes of authority. Instead, what takes place is a reaffirmation, a resuscitation of an ideal template." ${ }^{27}$ Dissent as opposition to what is politically and culturally accepted would be lacking, and in particular, there would be nothing similar to dissent beyond the given system. 'Transcendence,' in this context, would only be conceivable as 'self-transcendence' in order to achieve accord with the already existing pattern. Such views have led to a certain understanding of the suppression of dissidents in the People's Republic of China, with the argument that a different order from the one given is unimaginable for the Chinese and fundamental deviance is a foreign body in their culture. As a matter of fact, this conviction also has adherents among Chinese dissidents themselves. When the Nobel Peace Prize laureate Liu Xiaobo 刘晓波 attacked the conformist intellectuals of his generation for their "submissiveness, parochialism and denial of independent thought," he attributed this to a "form of thought" characterized by "lack of transcendence": "My tragedy is that I do not have transcendent values, it is the tragedy not to have a god." 28

Another exponent of the immanence paradigm is François Jullien. ${ }^{29}$ According to Jullien, Chinese ethics is "deeply conformist" 30 and "deliberately

Chinese and Western Culture (Albany, NY: SUNY Press, 1998), 207.

26 Virginia Suddath, "The Junzi Doth Protest: Toward a Philosophy of Remonstrance in Confucianism," PhD Dissertation, University of Hawai'i at Mānoa, 2005, 179.

27 Virginia Suddath, "Ought We Throw the Confucian Baby Out with the Authoritarian Bathwater?," in Confucian Cultures of Authority, ed. Peter Hershock and Roger T. Ames (Albany, NY: SUNY Press, 2006), 225.

28 Liu Xiaobo 劉曉波, Zhongguo dangdai zhengzhi yu Zhongguo zhishifenzi 中國當代政治與 中國知識分子 (Taipei: Tangshan, 1990), 156.

29 For a critique see Heiner Roetz, "Die Chinawissenschaften und die chinesischen Dissidenten: Wer betreibt die 'Komplizenschaft mit der Macht'?," in Bochumer Jahrbuch zur Ostasienforschung 35 (2011); Heiner Roetz, "Who is Engaged in the 'Complicity with Power'? On the Difficulties Sinology has with Dissent and Transcendence," in Transcendence, Immanence and Intercultural Philosophy, ed. Nahum Brown and William Franke (Basingstoke: Palgrave, 2016).

30 François Jullien, La propension des choses (Paris: Seuil, 1992), 338. 
teaches us opportunism." ${ }^{31}$ It merely reifies the given world instead of questioning it. Jullien relates this - like Lohmann - to the nature of the Chinese language, which allegedly presents the constant flow of events rather than allowing the "construction" of a "position" above and beyond it. This lack of "distance" leads to the "impossibility of dissidence" and a chronic "objective complicity" with power. ${ }^{32}$ According to Jullien, this is because Chinese culture is one without transcendence. China neither knows the "idea of a better future" nor does it have a "desire to strive for goals or a vocation."33 Everything remains within the spell of pure immanence. Instead of pursuing a telos that goes beyond the world, there is a self-immersion into the "subjectless process" - an idea which reminds me of Althusser's Paris rather than Peking $^{34}$ - by way of reducing action to a minimal control of the potentials that reveal themselves spontaneously in each moment. In the words of JeanFrançois Lyotard in his essay "François Jullien, Une pensée de biais":

There is no ideal, no reachable goal, which guides the will and perhaps even suggests means, which would be able to change the present situation accordingly - such a Western conception of effort is apparently unknown to the Chinese classics of war, of politics, of diplomacy and naturally also of the art of thinking. ${ }^{35}$

The same picture of China is drawn by Jean François Billeter who, despite presenting himself as a harsh critic of Jullien, basically shares his view. Billeter maintains that, in China, it was impossible to confront the ruler

with anything - neither bloodline, nor any legal, moral or religious principle. His power was not $[\ldots]$ subordinated to any (divine or other) transcendence. [...] Empirical power has in reality been mostly limited; however, in terms of principle, it has never been limited, neither by way of a division of power or law, nor by way of any ethical or religious transcendence, which would be independent of his power and which one could have appealed to against this power. ${ }^{36}$

31 François Jullien, Der Umweg über China: Ein Ortswechsel des Denkens (Berlin: Merve, 2002), 111.

32 François Jullien, "The Impossibility of Dissidence," chap. 6 in Detour and Access: Strategies of Meaning in China and Greece (New York, NY: Zone Books, 2000).

33 François Jullien, "Unterwegs: Strategie und Risiken der Arbeit von François Jullien," in Kontroverse über China: Sino-Philosophie, ed. Dirk Baecker et al. (Berlin: Merve, 2008), 78, 81.

34 Roetz, "Who is Engaged in the 'Complicity with Power'?," 297.

35 François Lyotard, "François Jullien: Une pensee de biais," Le Monde, April 4, 1997.

36 Jean François Billeter, "Kritik der chinesischen Zivilisation," Asiatische Studien/Études Asiatiques 50, no. 1 (1996): 15, 22. 
Are these theories on 'Chinese civilization' correct? Is the Chinese world one without distinctions like the ones 'we' know? Does China merely reify "that which is" (ce qui est, Billeter) because it does not know any transcendence? Is there an identity of the secular and the sacred, and is Chinese culture in all these aspects radically distinct from the West and Western modernity in particular? And is subjectlessness the reverse side of total immanence? Is the substance paradigm, rather than a subjectivity paradigm, an appropriate basis for understanding Chinese culture? With regard to all three of the actor-world relations, my answer to these questions would be "no." As a matter of fact, though the substance paradigm has been of tremendous influence, it has not remained unchallenged. I leave aside here that European Enlightenment already knew that Chinese materials made accessible by Jesuit translations could be read quite differently, namely as testimonies to the claim of moral autonomy. ${ }^{37}$ I will instead turn to a late revival of this kind of interest in China in the $20^{\text {th }}$ century - to Karl Jaspers' thesis of the Axial Age. It was presented in 1949 in his book Vom Ursprung und Ziel der Geschichte with which he wanted to draw a lesson from the German crimes of the Second World War.

Jaspers develops his hypothesis ${ }^{38}$ in direct contrast to Hegel's claim that the appearance of Christ is the axis ${ }^{39}$ of world history. The reason Jaspers wanted to overcome this prevalent mindset of the West is that it has contributed to the 'disaster of the occident,' the "claim to exclusiveness," which in its German radicalization ultimately led to the horrors of War. Against this pretension, Jaspers highlighted that 'world history' has multiple origins and not merely one. Its true 'axis', he said, is not the birth of Christianity but the earlier birth of the ancient prophecies and philosophies in quite a number of Eurasian regions - with China being one of them - at a time of simultaneous civilizational crises that shook existing political, economic and social conditions. Although independent of each other and distinct in their concrete contents, these movements all share a structural

37 See Heiner Roetz, "The Influence of Foreign Knowledge on Eighteenth Century European Secularism," in Religion and Secularity, ed. Marion Eggert and Lucian Hölscher (Leiden: Brill, 2013).

38 See Heiner Roetz, "The Axial Age Theory: A Challenge to Historism or an Explanatory Device of Civilization Analysis?," in The Axial Age and its Consequences, ed. Robert N. Bellah and Hans Joas (Cambridge, MA: Harvard University Press, 2012); Heiner Roetz, "Die Achsenzeit im Diskurs der chinesischen Moderne," Polylog 38 (2017).

39 Hegel: 'Angel' - 'hinge' obviously not correctly memorized by Jaspers. 
commonality that reveals a basic unity of mankind and allows Jaspers to speak of a turning point in world history. All of them are marked by the same decisive steps:

- A breakthrough through the unquestioned presence and closedness of life. Man "inwardly confronts the whole world" and "transcends the world and himself."

- Calling into doubt what Hegel calls "substance": "Opinions, customs, conditions that had been unconsciously accepted were now scrutinized, questioned, dissolved."

- The development of personhood and self-consciousness - of what Hegel calls "subjectivity."

- Taking steps towards critical, detached thinking (second order reasoning).

- Taking "steps towards the universal" by "reaching beyond oneself" and "recognizing oneself in the other" rather than reifying what is one's own. This delivers a kind of historical proof - what Kant calls a prognosticon (Der Streit der Fakultäten) - of the possibility of a different history from the one that led to the $20^{\text {th }}$ century disaster, of a future history of overcoming the logic of self-assertion by "boundless communication."

China being an Axial Age culture puts it on an equal footing with the West and reverses Hegel's negative judgment. In China, the same steps to subjectivity are being made as in the West, and this changes the entire foundation of the debate on China and modernity. On the basis of the Axial Age 'breakthrough,' modern consciousness in terms of Hegel's criterion of subjectivity also has a history in China and would not merely be a foreign import. Chinese culture is one of transcendence in terms of taking a step beyond the given stage of things, at least in its classical philosophies.

Although Jaspers also uses the notion of transcendence with a religious meaning, it should - as the above quotations show - initially be understood in a general, formal sense, as in Benjamin Schwartz's splendid definition, that transcendence is "a kind of standing back and looking beyond, a kind of critical, reflective questioning of the actual and new vision of what lies beyond."40 I think that this captures Jaspers' own idea. From this perspective, 'transcendent' religions like Christianity would not be 'axial' per se (which, if I understand him correctly, is Hans Joas' view), at least not

40 Benjamin Schwartz, “The Age of Transcendence," Daedalus 104, no. 2 (1975). 
in the sense of 'world history.' They would, rather, have to transcend themselves instead of occupying the distance they have created, again by their own claim to exclusiveness. In fact, Jaspers does not think that the content of religious beliefs and of revelations in particular can be universalized. This implies that transcendence can also be conceived of within a secular or - given the absence of an other-world - 'immanent' realm, where it then constitutes a structural rather than ontological difference.

I suppose that such a 'secular' concept of transcendence is well founded since transcendence can be seen as structurally rooted in human culture and human language itself, which, after all, is not a natural phenomenon: Human culture is based on constantly transcending physical borders to create an artificial surplus because of the "eccentric positionality" of the human being as a deficient being and the "mediated immediacy" of human life. ${ }^{41}$ This fact also seems to be co-extensive with the symbolic dimension of human language that can "infinitely transcend" ${ }^{42}$ the ce qui est $t^{43}$. If this is true, the possibility of transcendence does not rest on the beyondness of a religious deity or of a metaphysical heaven of ideas, to which humans can then appeal against the Earthly world - in fact, what has been done and has certainly exerted 'leverage' historically - but, reversely, the possibility of religious transcendence rests on the 'secular' semiosis of human language as part of human culture with an indirect reference to symbols. Denying the Chinese the possibility of transcendence would merely be equivalent to viewing their language as a non-human language. Lohmann has, in fact, compared it to the language of the Neandertal and the ape. ${ }^{44}$

The Axial Age would then be the age of the world-historical first reflective release of the inherent 'transcending' potential of the human language by consciously crossing the "symbolic threshold" 45 on a broad level. Jaspers' Axial Age hypothesis would thus provide an alternative heuristics to Hegel's heuristics of 'substance.' It would allow the reconstruction of Chinese philosophy as breaking through 'substance' towards subjectivity

41 Helmut Plessner, Die Stufen des Organischen und der Mensch: Einleitung in die philosophische Anthropologie (Berlin: De Gruyter, 1975).

42 Matthias Jung, Der bewusste Ausdruck: Anthropologie der Artikulation (Berlin: De Gruyter, 2009), 190.

43 Roetz, "Who is Engaged in the 'Complicity with Power'?, 302.

44 Lohmann, Philosophie und Sprachwissenschaft, 173.

45 Terrence Deacon, The Symbolic Species: The Co-evolution of Language and the Brain (New York, NY: Norton, 1997), 79. 
and a first anticipation of modern consciousness in terms of Hegel's notion of the modern.

However, this understanding of Jaspers' Axial Age hypothesis is thwarted by the most prominent subsequent adaptation - S. N. Eisenstadt's theory of Multiple Modernities (MMT). This theory counters the assumption that 'modernization' is the process that took place in the West and then is or has to be copied in other regions by overcoming the obstructive remains of traditional cultures. This formerly wide-spread assumption has been called into question from around the 1970s onwards. One of the reasons for this was East Asia's rapid economic boom, which for some observers was hard to explain as a simple 'appropriation' of the Western model without an indigenous basis. The explanation gap was filled by MMT, which assumes that modernity developed in the West but over the course of its global expansion has not merely brought forward variants of one and the same model. Rather, European modernity has merged with non-Western cultures in such a way that several 'modernities' have come into existence which do not converge in one common pattern that would, among other things, comprise a "democratic revolution." ${ }^{46}$ Modernity is then little more than a name for this complex and heterogeneous global situation itself: It is Western modernity plus the sum of reactions to the challenges emanating from it. These reactions are shaped by different cultural 'ontologies', 'cosmologies' and 'epistemologies, ${ }^{37}$ similar to the belief systems of great 'world religions.' These ontologies constitute the persistent 'core identities' of the respective societies which have taken form in "much earlier periods of cultural crystallization." 48

It is here where the Axial Age thesis comes in: In MMT, it is used to explain the formation of distinct great civilizations from different 'axial' periods where those specific 'cultural ontologies' and 'core identities' took shape, which, in turn, later defined various modernities. The Axial Age thesis would therefore refer to the emergence of a plurality of distinct, stable, longue durée cultural patterns of equal value existing beside one other, rather than converging or enabling Jaspers' "boundless communication."

46 Björn Wittrock, "Modernity: One, None, or Many? European Origins and Modernity as a Global Condition," Daedalus 129, no. 1 (2000).

47 Wittrock, "Modernity: One, None, or Many?"

48 Wittrock. 
This is a completely different understanding of modernity from the one relating to the release of subjectivity, which implies a critical rather than affirmative attitude towards the given state of things and tradition. MMT thus reintroduces a form of the immanence paradigm to the same theory that it had originally overcome. This makes the Axial Age idea and MMT exploitable by cultural exclusivism, as in today's China: China's participation in the Axial Age is taken as a license for self-sufficiency - it means membership in the club of 'great civilizations' that can rely on themselves and may not be commanded by others. ${ }^{49}$ Jaspers is even quoted by the General Secretary of the Chinese Communist Party, Xi Jinping. ${ }^{50}$ It is tragically ironic that the reformulation of the Axial Age idea by MMT results in the pretense to uniqueness appearing again. Therefore, what has happened to Jaspers' Axial Age thesis in MMT?

- The normative universalistic perspective has been replaced by an explanatory and descriptive perspective of historical sociology.

- The world-historical perspective (the axis as the moment when the unity of mankind becomes imaginable in an exemplary manner) has been replaced by a perspective on culture-specific axes in the plural as the founding phases of different histories.

- The perspective on mankind has been replaced by the perspective on a plurality of great civilizations.

- The future perspective has been replaced by a retrospective on the formation of longue durée civilizational patterns.

I am not calling into question the fruitfulness or even necessity of a sociological approach to the Axial Age hypothesis, but simply calling to mind the normative essence of Jaspers' idea and particularly the implications of the shared breakthrough towards subjectivity that tend to get lost when applying the MMT approach.

Still, Jaspers, in his "historical Platonism" (Habermas), links his normative program to an empirical historical hypothesis. His theory, therefore, has to stand some philological test, and it has been debated whether it is able to do so. Who is right, then, with regard to interpreting classical Chinese thought? For the sake of brevity, I cannot go into all three of the actor-world relations mentioned above and will limit myself to the first relation (man-nature, or subject-object), which is also most directly related

49 See Roetz, "Die Achsenzeit im Diskurs."

50 Roetz, 69. 
to the question of secularity. I will thus leave aside the components of subjectivity in the other relations, such as the claim to autonomy, the critique of tradition and the formulation of non-conventional moral norms. ${ }^{51}$

The ancient Chinese were well aware of the fact that human culture is based on distinctions. I quote the Confucian philosopher Xunzi 荀子from the $3^{\text {rd }}$ century BCE, who says, "That by which the human being is a human being is not to have two feet and no feathers. It is to know distinctions." ${ }^{32}$ "Distinctions" here first of all means social distinctions that humans have in contrast to animals. Xunzi also introduces a much more fundamental distinction that forms the basis of his entire philosophy, and this is the "difference between man and nature (lit: Heaven)," of which he says that he who has understood it is an "accomplished person." ${ }^{3}$ The human being is not embedded in nature but has been left unfinished by it (the natura noverca motif). It has to transform or reshape nature in accordance with its own regularities (chang 常) that work irrespective of human actions or intervention by spirits. ${ }^{54}$ In doing so, man "brings to completion" (cheng 成) what nature has only "brought into existence" (sheng 生). A new anthropogenic order is superimposed on the given, constant order of nature, which cannot be changed but can be utilized precisely by following it - an anticipation of Francis Bacon's natura parendo vincitur. As Xunzi says in his treatise On Nature,

To gaze in wonder at nature (lit.: Heaven, see below) and to fix one's thoughts upon it - how could this compare to domesticating it like a thing and having it at one's disposal?

To follow nature and sing its praises - how could this compare to tailoring its disposition [to one's own purposes] and making use of it?

To look for a favourable moment in time and wait for it - how could this compare to reacting to every moment and getting it to work for one?

To run after things and to let them increase - how could this compare to unleashing one's abilities and changing things?

To train one's thoughts on things and letting them be things - how could this compare to conferring order upon them and not suffering their loss?

51 See Heiner Roetz, "Zu den Antizipationen modernen Denkens in der chinesischen Philosophie der Achsenzeit," in Archäologie der Moderne, ed. Alfred Schmid et al. (Basel: Schwabe, 2020).

52 Xunzi, 5: “人之所以為人者, 非特以其二足而無毛也, 以其有辨也.”

53 Xunzi, 17: “明於天人之分則可謂至人矣.”

54 See Roetz, Mensch und Natur, 331-36. 
To want to be with that through which the things come about nature - how could this compare to being in possession of that through which things come to perfection?

Whoever therefore leaves man aside and devotes his thoughts to nature, that person has failed to understand the true condition of things! ${ }^{15}$

The manipulation of nature demanded by Xunzi would not be possible if nature were a realm under the control of gods and spirits rather than a secular realm with its own regularity. For Xunzi, a - in modern terms 'religious' view of nature as a non-secular realm is only the view shared by stupid people, not by an enlightened scholar:

What does it mean if it rains after a rain ritual has been performed? I say, it means nothing. It is just as if it had rained after no rain ritual had been performed. When a saving ritual is held when the sun and the moon are eclipsed, when a rain ritual is performed in a drought, and when the oracle is consulted before important decisions - these things are not done in hope of achieving the desired result, but for the sake of culture (wen 文). Therefore, a gentleman (the true Confucian) regards them as [an expression of] culture (wen), but the people regard them as something divine (shen 神). To regard them as culture is auspicious, to regard them as something divine leads to calamity. ${ }^{56}$

Without distorting the text, one could also render shen as 'something religious' in a free translation.

There is a similar distinction between shen 神 (spirits, deities) and shu 數 (numerical relations in nature) in the Chunqiu fanlu 春秋繁露, traditionally attributed to the Han Confucian Dong Zhongshu 董仲舒 (ca. 179104). In the Chapter Tong lei xiang dong 同類相動 Things of the same kind move each other, which actually elaborates ideas from the Lüshi Chunqiu 呂 氏春秋, a text from the $3^{\text {rd }}$ century BCE, we read:

Water poured on level ground will avoid the dry parts and move towards the wet ones. If firewood is exposed to fire, fire will avoid the damp parts and ignite the dry ones. All things reject what is different and follow what is akin to them. Thus it is that if the qi is similar, [things] will coalesce, and if the voices correspond, they will answer each other. There is very clear evidence for this. Let us tune [two] zithers and position them. Strike the gong

55 Xunzi, 17, Tian lun: “大天而思之, 孰與物畜而制之! 從天而頌之, 孰與制天命而用之! 望時而 待之, 孰與應時而使之! 因物而多之, 孰與駎能而化之! 思物而物之, 孰與理物而勿失之也! 願於 物之所以生, 孰與有物之所以成! 故錯人而思天, 則失萬物之情.”

56 Xunzi, 17: “零而雨何也? 曰無何也. 猶不零而雨也. 日月食而救之, 天旱而零, 卜筮然後決大事, 非以為得求也, 以文之也. 故君子以為文, 而百姓以為神. 以為文則吉, 以為神則凶也.” 
note on the one, and the other gong note will respond. Strike the shang note on the one, and the other shang note will respond. [In the same way], any similar note among the five notes will automatically ring. It is not that that is something divine (shen, or: miraculous) in this; it is so because of the numerical [correlations] $(s h u)$. If beautiful things summon things of their category, and ugly things summon things of their category, this is caused by the correspondence of their categories, as for instance if a horse whinnies another horse will answer, and if a cow lows another cow will answer. [Similarly], when an emperor or king is about to rise, auspicious omens will first appear, and when they are about to perish, baleful omens will first appear. Therefore, things summon each other according to their categories. So one brings about rain by the dragon, and drives away heat by the fan. [...]

Heaven has yin and yang, and man also has yin and yang. When the yin-power of Heaven and Earth rises, the yin-power of man will also rise in response. And when the yin-power of man rises, the yin-power of Heaven and Earth will also rise in response. This is one and the same principle (dao). He who is clear about this will activate the yin and thereby make it rise, if he wants to bring about rain. And if he wants to stop rain, he will activate the yang and thereby make it rise. Therefore, bringing about rain is nothing divine (shen). The reason that one suspects it has to do with gods/spirits (shen) is that its rules are very subtle. It is not only the yin- and the yang-power that can, on the basis of [correspondence to] categories, be made to advance and retreat. Even the origin of baleful omens, of misfortune and fortune, comes from here. There is nothing that would not have been stimulated beforehand by something, and things move in reaction according to their categories. [...] Thus it is that if you strike the gong note on one zither, the other gong note will automatically ring in response. This is the movement of things according to categories. However, since it is moved by the sound without a visible shape, one calls it 'ringing by itself'. Since also moving each other is without shape, one calls it 'by itself so'. In reality, it is nothing that is by itself so, but there is something that has caused it to be so. [All] things naturally are really caused by something, but it is without shape. ${ }^{57}$

While Xunzi set up the alternative of shen 神 vs. wen 文, as a matter of spirits vs. culture, the author of the treaties Tong lei xiang dong of the

57 Chunqiu fanlu, 57 Tong lei xiang dong: “今平地注水, 去燥就濕. 均薪施火, 去濕就燥. 百物去 其所與異而從其所與同. 故氣同則會, 聲比則應, 其驗皦然也. 試調琴瑟而錯之,鼓其宮則他宮應 之, 鼓其商而他商應之. 五音比而自鳴, 非有神, 其數然也. 美事召美類, 惡事召惡類, 類之相應而 起也. 如馬鳴則馬應之, 牛鳴則牛應之, 帝王之將興也, 其美祥亦先見, 其將亡也, 妖蒘亦先見. 物 故以類相召也. 故以龍致雨, 以扇逐暑. [...]有陰陽, 人亦有陰陽. 天 地之陰氣起而人之陰氣應之 而起. 人之陰氣起而天地之陰氣亦宜應之而起. 其道一也. 明於此者, 欲致雨則動陰以起陰, 欲止 雨則動陽以起陽. 故致雨非神也. 而疑於神者, 其理微妙也. 非獨陰陽之氣可以類進退也, 雖不祥 禍福所從生, 亦由是也. 無非己先起之, 而物以類應之而動者也. [...] 故琴瑟報彈其宮, 他宮自鳴 而應之, 此物之以類動者也. 其動以聲而無形, 人不見其動之形, 則謂之自鳴也. 又相動無形, 則 謂之自然. 其實非自然也, 有使之然者矣. 物固有實使之, 其使之無形.” 
Chunqiu fanlu sets up the alternative of shen 神 vs. shu 數, as a matter of spirits vs. numerical correlations or a numerological technique based on "evidence" (yan 驗) and validated by an experiment, thus presented as a kind of natural science. In both cases, a clear distinction is drawn between religious and non-religious conception, underlined by the use of the negation $f e i$ 非 (it is not that ...). The usage of shen in these arguments corresponds to a possible usage of the word 'religion' or 'religious' - at least if one follows the conventional, certainly disputed but defendable understanding of religion as belief in and veneration of deities (in any case, classical Chinese examples show how problematic it would be to understand religion primarily in terms of ritual, let alone to blur the delimitation of religion and culture). The fact that the terms 'religious' and 'secular' may belong to 'our' descriptive terminology does not, as I see it, imply that it is also 'only we as observers' who make the distinction ${ }^{58}-$ it is simply expressed in another way. If the ancient Chinese had had the word 'religious' at their disposal, it would have made sense to them and they would have had no problem using it.

What is behind these shifts towards the non-religious understanding of the processes of nature among the educated elite (the 'scholars') in ancient China? Its history dates back to the early Zhou dynasty $\left(11^{\text {th }}-3^{\text {rd }}\right.$ century BCE). It starts with the crisis of the religion of "Heaven" (Tian 天), the highest God in the worldview of the early Zhou, who is in control of all Earthly matters and interfering with politics and nature to secure the way of virtue. This belief loses credibility during the chaotic breakdown of the Zhou dynasty from the $9^{\text {th }}$ century BCE, in which Tian does not intervene. Tian by and large loses its religious aura and is finally secularized to the notion of dysteleological 'nature' in late Zhou thought, a process driven forward in Daoism and ultimately reaching its peak in Xunzi's philosophy. ${ }^{59}$ All moral and political norms now count as human inventions, created by conscious "art" (wei 偽). The human world is discovered as a world sui generis and no

58 Hubert Seiwert, "Ancestor Worship and State Rituals in Contemporary China: Fading Boundaries between Religious and Secular," Zeitschrift für Religionswissenschaft 24, no. 2 (2016): 133.

59 See Roetz, Mensch und Natur; Heiner Roetz, "Die Internalisierung des Himmelsmandats: Zum Verhältnis von Konfuzianismus und Religion," in Transcending Boundaries: Practical Philosophy from Intercultural Perspectives, ed. Walter Schweidler (St. Augustin: Academia, 2015). 
longer under the sway of gods and spirits. This opens up a space for subjectivity to develop. The subject-object relation between tian 天 and ren 人 is reversed: In the early Zhou era, the world is controlled by tian as Heaven; by the end of the Zhou era, tian as nature is under man's control.

Certain significant developmental stages of this process are found in ideas dating from the $6^{\text {th }}$ century BCE, once the Zhou territory disperses into a number of independent states and China is facing a long conflict between the former Zhou vassals. China goes through one of the deepest social, political and mental crises in its history. Philosophical thinking is born, challenged to freshly conceive man's position in the world. When a comet, traditionally regarded as a sign from Heaven, appears over the state of Zheng, astrologers ask to perform a ritual to avert a fire disaster. The enlightened chancellor Zichan 子產 (?-522 BCE) refuses, and Zheng - as predicted - suffers a fire. Despite all warnings, Zichan rejects the request a second time. As he says, the "way of Heaven" (tian dao 天道) cannot be influenced by the "way of man" (ren dao 人道) since both are different things:

The way of Heaven is distant, while the way of man is near. We cannot reach the former; what means do we have of knowing it?60

Zichan sets the course for viewing mundane matters as a realm for themselves, and to direct one's attention to the human world rather than to gods and spirits. This attitude leads to a novel understanding of sacrifice as a cultural rather than a religious act and a matter for humans rather than gods. ${ }^{61}$ According to Guanshe Fu 觀射父 from the state of $\mathrm{Chu}$ - a contemporary of Confucius (551-479) - one should in sacrifice "be respectful and neat, as if someone were looking from above." 62 The "as if" idea reappears in Confucius's own view of religious ritual:

Sacrifice [to the spirits] as if [the spirits] were present. The Master said: If I do not take part in (= am not mentally present) the sacrifice, it is as if I do not sacrifice. ${ }^{63}$

What is important, then, is that during sacrificial rites oneself is 'present.' It is not decisive whether or not there are spirits or gods. This is later repeated and elaborated by Xunzi:

60 Zuozhuan Zhaogong, 18: “天道遠, 人道速, 非所及也. 何以知之?”

61 Roetz, Mensch und Natur, 178-209; Seiwert, "Ancestor Worship," 131-32.

62 Guoyu Chu B2: “肅肅濟濟如或臨之.” See Roetz, Mensch und Natur, 190.

63 Lunyu 3.12: “祭如在, 祭神如神在. 子曰: 吾不與祭, 如不祭.” 
Thus I say: The sacrificial rites are the refined expression of remembrance and longing. They are the utmost in loyalty, trustworthiness, love, and respect. They are the fullest manifestation of ritual, proper regulation, good form, and proper appearance. If one is not a sage, then one will not be able to understand them. The sage clearly understands them. The well-bred man and the gentleman are at ease in carrying them out. The officials take them as things to be preserved. The common people take them as their set customs. The gentleman regards them as the way to be a proper human being. The common people regard them as serving the ghosts....

For the ritual sacrifices, one engages in divination and determines the appropriate day. One fasts and sweeps out the site, sets out tables and food offerings, and has the 'announcement to the assistant,' as if the deceased were attending a banquet. The impersonator of the dead takes the goods and from each of them makes a sacrifice, as if the deceased were tasting them. No helper raises the toast, but rather the host himself takes hold of the cup, as if the deceased were engaging in the toast. When the guests leave, the host sends them off and bows to them as they go, then returns and changes his clothing. He goes back to this position and cries, as if the deceased had left. How full of sorrow! How full of respect! One serves the dead like one serves the living, and one serves the departed like one serves a surviving person. One gives a shape to that which is formless and in magnificent fashion accomplishes cultivated demeanor." ${ }^{\prime 4}$

The Confucian "gentleman" therefore understands sacrifice as a cultural act and no longer a religious one as the common people do, and this actually reappears over 2000 years later in the Rites Controversy. Seemingly 'religious' acts now become elements of self-cultivation rather than being a service to spirits. The Confucians are attacked for this position as dangerous "spirit deniers" 65 by their Mohist critics. ${ }^{66}$

To conclude, when researching the breakthrough through 'substance' in China, I have briefly looked at literature dating from the last centuries of the Zhou period, focusing on shifts in the relation of man and nature. For a less impressionistic picture, it is also necessary to address the other two

64 Xunzi 19 Lilun, On the Rites, translation: Eric Hutton, Xunzi, The Complete Text, modified: “故曰: 祭者志意思慕之情也. 忠信愛敬之至矣, 禮節文貌之盛矣. 苟非聖人, 莫之能知也. 聖人明知之, 士君子安行之, 官人以為守, 百姓以成俗. 其在君子以為人道也, 其在百姓以為鬼 事也. [...]筮視日齋戒脩涂几䇥饋薦告祝, 如或饗之. 物取而皆祭之, 如或嘗之. 冊利舉爵, 主 人有尊, 如或觞之. 賓出, 主人拜送, 反易服, 即位而哭, 如或去之. 哀夫! 敬夫! 事死如事生, 事亡 如事存. 狀乎無形, 影然而成文.”

65 執無鬼者.

66 Mozi 31 and 48; Roetz, Die chinesische Ethik, 377-78; Roetz, “Die Internalisierung," 152. 
actor-world relations, as well as how the three link together. ${ }^{67}$ However, the materials quoted should sufficiently show that - in contrast with that assumed in the radical immanence-paradigm following the Hegelian model of 'substance' - a process of world disenchantment is taking place in Axial Age China accompanied by a shift in agency from spirits to men and thus providing leeway for recourse to subjectivity. This does not signify that such recourse would be impossible for religious consciousness - it might even be strengthened in individual communication with an otherworldly God - but that it is hardly conceivable in a homologue, compact world where everything is sacred. The difference itself is what makes the difference.

The ancient Daoists have described how such a primordial unitary oikumene was destroyed by man after the awakening of the calculating human intellect, leading to a "torn-apart" world ${ }^{68}$ and ending in an apocalyptic "age of downfall." ${ }^{69}$ What they discover is the dark side of subjectivity, its tendency to make itself independent, and once set free, not only resulting in the total objectification and ultimately in the destruction of nature, but also in the total objectification of co-subjects, as with its monopolization by the political elite. This occupation that shows the need for another, non-monological paradigm of subjectivity ${ }^{70}$ happened again and again in Western and in Chinese history. In fact, it also happened in Maoist China, which brings me back to the beginning of my paper. However, this only corroborates my hypothesis that, when dealing with the question of subjectivity as the key notion of secular modernity, China does not deliver a model to counter the West, for better or worse.

67 See Roetz, "Zu den Antizipationen modernen Denkens."

68 Zhuangzi 9, 11, 16, 33; Roetz, Mensch und Natur, 251-69.

69 Huainanzi 8; Heiner Roetz, "Chinese 'Unity of Man and Nature': Reality or Myth?," in Nature, Environment and Culture in East Asia: The Challenge of Climate Change, ed. Carmen Meinert (Leiden: Brill, 2013), 36.

70 See Heiner Roetz, "Human Rights in China: An Alien Element in a Non-Western Culture?," in Human Rights and Natural Law: An Intercultural Philosophical Perspective, ed. Walter Schweidler (St. Augustin: Academia, 2012), 307-10; and from a different perspective, Fabian Heubel, Chinesische Gegenwartsphilosophie (Hamburg: Junius, 2016), 111-28. 


\section{Bibliography}

Classical Chinese sources are quoted after Chinese Text Project.

Billeter, Jean François. "Kritik der chinesischen Zivilisation." Asiatische Studien/Études Asiatiques 50, no. 1 (1996): 1-27.

Davis, Scott. "Two Neglected Classics of Comparative Ethics." Journal of Religious Ethics 36, no. 3 (2008): 375-403.

Deacon, Terrence. The Symbolic Species: The Co-evolution of Language and the Brain. New York, NY: Norton, 1997.

Fingarette, Herbert. Confucius: The Secular as Sacred. New York, NY: Harper Torchbooks, 1972.

Fingarette, Herbert. "Reason, Spontaneity, and the $L i$ : A Confucian Critique of Graham's Solution to the Problem of Fact and Value." In Chinese Texts and Philosophical Contexts: Essays Dedicated to Angus C. Graham. Edited by Henry Rosemont, 209-26. La Salle: Open Court, 1991.

Habermas, Jürgen. Handlungsrationalität und gesellschaftliche Rationalisierung. Vol. 1 of Theorie des kommunikativen Handelns. Frankfurt/M.: Suhrkamp, 1985.

Hall, David, and Roger Ames. Thinking from the Han: Self, Truth and Transcendence in Chinese and Western Culture. Albany, NY: SUNY Press, 1998.

Hegel, G. W. F. Vorlesungen zur Philosophie der Weltgeschichte. Vol. 9 of Werke. Leipzig: Meiner, 1920.

Hegel, G. W. F. Vorlesungen über die Philosophie der Religion. Vol. 16 of Werke. Frankfurt/M.: Suhrkamp, 1986.

Hegel, G. W. F. Grundlinien der Philosophie des Rechts. Vol. 7 of Werke. Frankfurt/M.: Suhrkamp, 1986.

Heubel, Fabian. Chinesische Gegenwartsphilosophie. Hamburg: Junius, 2016.
Jaspers, Karl. Vom Ursprung und Ziel der Geschichte. München: Piper, 1949.

Jullien, François. La propension des choses. Paris: Seuil, 1992.

Jullien, François. Detour and Access: Strategies of Meaning in China and Greece. New York, NY: Zone Books, 2000.

Jullien, François. Der Umweg über China: Ein Ortswechsel des Denkens. Berlin: Merve, 2002.

Jullien, François. "Unterwegs: Strategie und Risiken der Arbeit von François Jullien." In Kontroverse über China: Sino-Philosophie. Edited by Dirk Baecker et al., 77-122. Berlin: Merve, 2008.

Jung, Matthias. Der bewusste Ausdruck: Anthropologie der Artikulation. Berlin: De Gruyter, 2009.

Liu Xiaobo 劉曉波. Zhongguo dangdai zhengzhi yu Zhongguo zhishifenzi 中國當代政治與中國知識分子. Taipei: Tangshan, 1990.

Lohmann, Johannes. "Martin Heideggers ontologische Indifferenz und die Sprache." Lexis 1 (1948): 49-106.

Lohmann, Johannes. Philosophie und Sprachwissenschaft. Berlin: Duncker \& Humblot, 1965.

Lyotard, François. "François Jullien: Une pensee de biais." Le Monde, April 4, 1997.

Parsons, Talcott. The Structure of Social Action. New York, NY: Free Press, 1937.

Plessner, Helmut. Die Stufen des Organischen und der Mensch: Einleitung in die philosophische Anthropologie. Berlin: De Gruyter, 1975.

Roetz, Heiner. Mensch und Natur im alten China: Zum SubjektObjekt-Gegensatz in der klassischen chinesischen Philosophie. Frankfurt/M.: P. Lang, 1984. 
Roetz, Heiner. Die chinesische Ethik der Achsenzeit: Ein Rekonstruktion unter dem Aspekt des Durchbruchs zu postkonventionellem Denken. Frankfurt/M.: Suhrkamp, 1992.

Roetz, Heiner. Confucian Ethics of the Axial Age. Albany, NY: SUNY Press, 1993.

Roetz, Heiner. "Die chinesische Sprache und das chinesische Denken: Positionen einer Debatte." In Bochumer Jahrbuch zur Ostasienforschung 30 (2006): 9-38.

Roetz, Heiner. "Die Chinawissenschaften und die chinesischen Dissidenten: Wer betreibt die 'Komplizenschaft mit der Macht'?' In Bochumer Jahrbuch zur Ostasienforschung 35 (2011): 47-79.

Roetz, Heiner. "The Axial Age Theory: A Challenge to Historism or an Explanatory Device of Civilization Analysis?" In The Axial Age and its Consequences. Edited by Robert N. Bellah and Hans Joas, 248-76. Cambridge, MA: Harvard University Press, 2012.

Roetz, Heiner. "Human Rights in China: An Alien Element in a Non-Western Culture?" In Human Rights and Natural Law: An Intercultural Philosophical Perspective. Edited by Walter Schweidler, 296-313. St. Augustin: Academia, 2012.

Roetz, Heiner. "The Influence of Foreign Knowledge on Eighteenth Century European Secularism.” In Religion and Secularity. Edited by Marion Eggert and Lucian Hölscher, 9-34. Leiden: Brill, 2013.

Roetz, Heiner. "Chinese 'Unity of Man and Nature': Reality or Myth?” In Nature, Environment and Culture in East Asia: The Challenge of Climate Change. Edited by Carmen Meinert, 23-39. Leiden: Brill, 2013.
Roetz, Heiner. "Die Internalisierung des Himmelsmandats: Zum Verhältnis von Konfuzianismus und Religion.” In Transcending Boundaries: Practical Philosophy from Intercultural Perspectives. Edited by Walter Schweidler, 145-58. St. Augustin: Academia, 2015.

Roetz, Heiner. "Erinnerung: 50 Jahre Kulturrevolution.” Bochumer Jahrbuch zur Ostasienforschung 39 (2016): 229-46.

Roetz, Heiner. "Who is Engaged in the 'Complicity with Power'? On the Difficulties Sinology has with Dissent and Transcendence." In Transcendence, Immanence and Intercultural Philosophy. Edited by Nahum Brown and William Franke, 383-17. Basingstoke: Palgrave, 2016.

Roetz, Heiner. "Die Achsenzeit im Diskurs der chinesischen Moderne." Polylog 38 (2017): 63-80.

Roetz, Heiner. "Zu den Antizipationen modernen Denkens in der chinesischen Philosophie der Achsenzeit." In Archäologie der Moderne: Antike und Antike-Rezeption als Paradigma und Impuls. Edited by Alfred Schmid et al. Basel: Schwabe, 2020 (forthcoming).

Russell, Bertrand. New Hopes for a Changing World. London: George Allen and Unwin, 1951.

Schelling, F. W. J. Philosophie der Mythologie. Vol. 1. Reprint. Darmstadt: Wissenschaftliche Buchgesellschaft, 1957 [1856].

Schwartz, Benjamin. "The Age of Transcendence.” Daedalus 104, no. 2 (1975): 1-7.

Seiwert, Hubert. "Ancestor Worship and State Rituals in Contemporary China: Fading Boundaries between Religious and Secular." Zeitschrift für Religionswissenschaft 24, no. 2 (2016): 127-52. 
Suddath, Virginia. “The Junzi Doth Protest: Toward a Philosophy of Remonstrance in Confucianism." PhD Dissertation, University of Hawai' $\mathrm{i}$ at Mānoa, 2005.

Suddath, Virginia. "Ought We Throw the Confucian Baby Out with the Authoritarian Bathwater?" In Confucian Cultures of Authority. Edited by Peter Hershock and Roger T. Ames, 215-45. Albany, NY: SUNY Press, 2006.
Weber, Max. "Konfuzianismus und Taoismus.” In Gesammelte Aufsätze zur Religionssoziologie I, Tübingen: Mohr, 1920.

Wittrock, Björn. "Modernity: One, None, or Many? European Origins and Modernity as a Global Condition." Daedalus 129, no. 1 (2000): 31-60. 



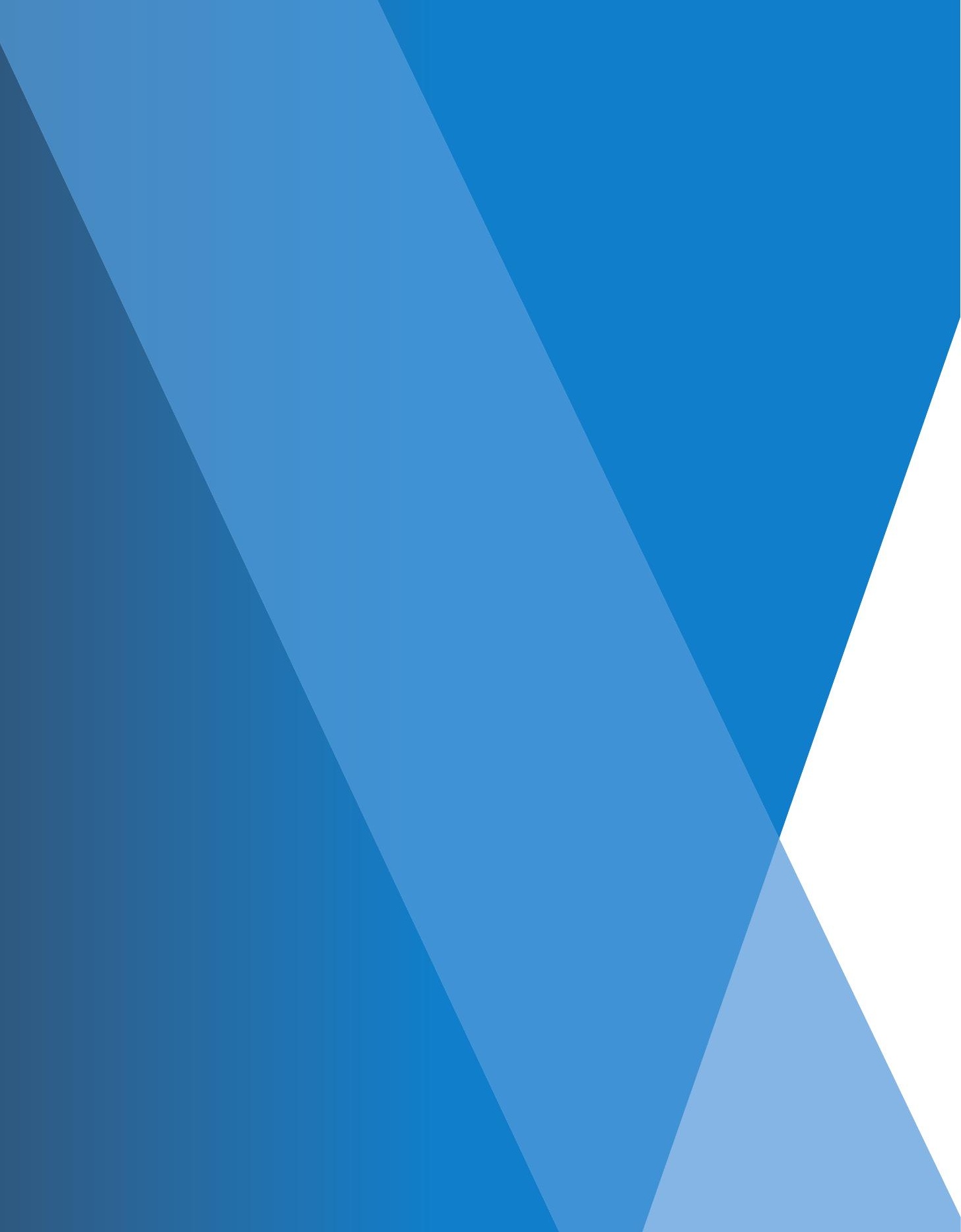

